\title{
OCHRONA AKCJONARIUSZY MNIEJSZOŚCIOWYCH PRZED NIEUZASADNIONĄ TEZAURYZACJA ZYSKU SPÓŁKI
}

\section{SFORMULOWANIE PROBLEMU}

Podział zysku w spółce kapitałowej jest źródłem złożonych zagadnień związanych $\mathrm{z}$ istota i normatywnym ukształtowaniem relacji korporacyjnej. Przepisy art. 191 i 347 Kodeksu spółek handlowych ${ }^{1}$ poddają powyższą kwestię kontroli większości na zgromadzeniu. Zgromadzenie może m.in. podjąć uchwałę o przeniesieniu zysku na kapitał rezerwowy lub wypłacie minimalnej dywidendy. Jak jednak wynika z orzecznictwa Sąu Najwyższego, powyższa uchwała, realizująca interes wyłącznie większościowych wspólników, może być uchylona przez sąd, jako sprzeczna z dobrymi obyczajami i mająca na celu pokrzywdzenie mniejszości ${ }^{2}$. Jednocześnie konsekwencje wyroku uchylającego nie są oczywiste, ponieważ nie zobowiązuje on pozwanej do wypłacenia wyższej dywidendy.

Istota oraz intensywność konfliktów na tle podziału zysku są zróżnicowane, co utrudnia klasyfikowanie ich jako jednego zagadnienia. Teoretyczna doniosłość takich sporów jest w dużym stopniu pochodną struktury udziałowej spółki. Zasada rządów większości wydaje się tym bardziej oczywista i trudna do podważenia, im większy udział w kapitale zakładowym ma dominujący inwestor (jego interes staje się wówczas wyznacznikiem interesu spółki). Mniej jednoznaczna jest sytuacja w spółce, w której udziały są wyrównane i należą do niewielkiej liczby wspólników (np. do dwóch, w proporcji 49:51). Z kolei praktyczna doniosłość sporów o dywidendę zależy od cech typologicznych spółek. Jest ograniczona w spółce akcyjnej, której akcje są wprowadzone do obrotu zorganizowanego (zwłaszcza na rynku regulowanym), ponieważ ich właściciele mogą sprzeciwić się rygorystycznej polityce dywidendowej, „głosując nogami” (sprzedając akcje). Zważywszy, że zatrzymanie zysku jest dodatnio skorelowane z wartościa papierów wartościowych emitenta, ich odpowiednio wyższa cena stanowi jednocześnie rekompensatę za brak dywidendy ${ }^{3}$. W tych

\footnotetext{
${ }^{1}$ Ustawa z 15 września 2000 r. - Kodeks spółek handlowych, t.jedn.: Dz. U. 2013, poz. 1030 ze zm. (dalej jako: k.s.h. lub „Kodeks”).

${ }^{2}$ Por. wyroki SN: z 16 kwietnia 2004 r., I CK 537/03; z 6 marca 2009 r., II CSK 522/08; z 21 maja 2010 r., II CSK 564/09; z 27 marca 2013 r.; I CSK 407/12 i z 28 marca 2014 r., III CSK 150/13.

${ }^{3}$ Nie jest to oczywiście zależność bezwzględna, którą w przypadku zaskarżenia uchwały tezauryzującej zysk sąd powinien przyjmować apriorycznie (por. uzasadnienie wyroku SN z 16 kwietnia 2004 r.).
} 
warunkach traci na znaczeniu klasyczne rozróżnienie między prawem (akcja) a pożytkiem z prawa (dywidenda) - czego wyrazem jest praktyka wypłacania dywidend w spółkach publicznych w formie akcji. Inną pozycję maja wspólnicy spółki z ograniczoną odpowiedzialnościa - którym trudniej jest sprzedać udziały. W patowych sytuacjach mogą oni jedynie rozważać powództwo o rozwiązanie spółki (art. 271 pkt 1 k.s.h.). Powyższe scenariusze nie wchodzą w rachubę bądź są utrudnione w tzw. zamkniętej spółce akcyjnej. Zbycie akcji jest $\mathrm{w}$ tym przypadku często niemożliwe $\mathrm{z}$ uwagi na brak płynnego rynku i wąsko ujęte przesłanki przymusowego odkupu (art. $418^{1}$ k.s.h.), a jednocześnie brak możliwości rozwiązania stosunku korporacyjnego na żądanie akcjonariusza.

Dalsze rozważania koncentrują się na takiej właśnie (zamkniętej) spółce akcyjnej. Niemniej część uwag ma charakter ogólny i może być odniesiona do spółki z ograniczoną odpowiedzialnością. Celem artykułu jest odpowiedź na pytanie, czy w przypadku abuzywnej praktyki ograniczania wypłaty zysku akcjonariusze mniejszościowi moga realnie chronić swoje interesy, oraz zasugerowanie kierunku zmian prawnych służących wzmocnieniu tej ochrony.

\section{CZY PRAWO DO ZYSKU PODLEGA OCHRONIE? UWARUNKOWANIA AKSJOLOGICZNE I UWAGI PRAWNOPORÓWNAWCZE}

W dotychczasowym orzecznictwie zagadnienie roszczeń akcjonariusza, związanych z uchyleniem przez sąd uchwały wyłączającej zysk od podziału, nie było szerzej komentowane. Natomiast uwaga doktryny skupiła się na analizie sankcji odszkodowawczej. Zdaniem Igora Komarnickiego pokrzywdzenie mniejszości wynikające z blokady dywidendy wiąże się zazwyczaj z powstaniem szkody, co może uzasadniać roszczenia wobec wspólników, którzy doprowadzili do powzięcia uchwały tezauryzacyjnej ${ }^{4}$. Sceptycznie na temat traktowania reżimu deliktowego jako płaszczyzny ochrony prawa do zysku wypowiedzieli się Andrzej Kidyba i Małgorzata Dumkiewicz ${ }^{5}$. Zdaniem tych autorów odpowiedzialność odszkodowawczą wspólników wyłącza brak związku przyczynowego między oddaniem głosu za tezauryzacja a wystapieniem szkody po stronie wspólników mniejszościowych, ponieważ - gdyby nawet takiej uchwały nie przegłosowano - nie jest pewne, czy i w jakiej części wynik finansowy zostałby przeznaczony przez zgromadzenie na wypłatę. Ponadto uchylenie przez sąd wspomnianej uchwały eliminowałoby zdarzenie wywołujące szkodę. Uznanie, że w określonych okolicznościach wspólnicy mają obowiązek głosować wyłącznie za podziałem zysku, podważałoby też sens poddawania takiej sprawy pod głosowanie ${ }^{6}$.

${ }^{4}$ I. Komarnicki, Prawo akcjonariusza do udziału w zysku, Warszawa 2007, SIP Legalis 2016.

${ }^{5}$ A. Kidyba, M. Dumkiewicz, Wybrane problemy zwiazane ze skutkami zaskarżania uchwat zgromadzeń spótek kapitałowych w przedmiocie podziału zysku, „Przegląd Prawa Handlowego” 2013, nr 11, s. 11-16.

${ }^{6}$ Ibidem. 
Listę argumentów podanych przez A. Kidybę i M. Dumkiewicz można wydłużyć. Wątpliwości budzi już samo posługiwanie się w analizowanym kontekście pojęciem szkody. Można twierdzić (tolerując tu pewne uproszczenie), że uchwała zatrzymujacca zysk w spółce nie tyle powoduje uszczerbek majątkowy udziałowców, ile determinuje strukturę ich aktywów (rzutuje na wartość księgową spółki, a tym samym jej akcji) ${ }^{7}$. Dywidenda może ponadto być wypłacona w przyszłości, co nie pozwalałoby mówić o „ustaleniu się” szkody. Oddanie głosu za tezauryzacją nie wykazuje też cech bezprawności, ponieważ poddanie takiej propozycji pod głosowanie tworzy po stronie głosujących uprawnienie kształtujące ${ }^{8}$, którego istotą jest możliwość (prawo) opowiedzenia się za przyjęciem lub odrzuceniem określonego projektu uchwały ${ }^{9}$. Ponadto decyzja o sposobie dysponowania wynikiem finansowym jest subiektywna i nie musi być jednolicie oceniana nawet w gronie wspólników mniejszościowych. Nie wpisuje się zatem w reguły odpowiedzialności deliktowej, bazujące na obiektywnej nieprawidłowości postępowania sprawcy ${ }^{10}$. Wspomniany brak bezprawności, a także ewentualny brak wiedzy na temat preferencji pozostałych wspólników, wykluczałby jednocześnie przypisanie winy głosującym, tj. podmiotową niewłaściwość ich zachowania. A priori dyskusyjny byłby też każdy rozkład odpowiedzialności wspólników za skutki powzięcia uchwały (brak jednoznacznych kryteriów przyczynienia się do „szkody”). Wreszcie sankcję odszkodowawczą podważaja argumenty natury funkcjonalnej (np. nie rozwiąuje ona problemu niestawiennictwa akcjonariusza na zgromadzeniu w przypadku zastrzeżenia kworum).

Wskazując na brak perspektyw do formułowania roszczeń odszkodowawczych, A. Kidyba i M. Dumkiewicz wyrazili również dalej idący pogląd, a mianowicie, że usunięcie z obrotu uchwały zatrzymującej zysk w spółce pozostaje bez wymiernego skutku w sferze praw wspólników, a w konsekwencji realizacja prawa do zysku w spółkach kapitałowych jest bezwzględnie podporządkowana zasadzie prymatu kapitału i rządów większości ${ }^{11}$. Stanowisko to sugeruje, że strukturalne uwarunkowania spółki kapitałowej nakazują pogodzić się z potencjalnie nieograniczonym w czasie pozbawieniem wspólników pożytków z akcji, bez względu na okoliczności.

Powyższe podejście może już jednak niepokoić zarówno w świetle istoty stosunku korporacyjnego, jak i ogólnych założeń aksjologicznych przypisywanych prawodawcy. Te ostatnie znajduja wyraz w takich przepisach, jak art. 3 k.s.h. (nakaz dążenia do realizacji wspólnego celu), art. 20 k.s.h. (jednakowe traktowanie wspólników), art. 249 § 1 i 422 § 1 k.s.h. (prawo zaskarżania uchwał zgromadzeń) czy art. $304 \S 4$ k.s.h. (zakaz wprowadzania do statutu postanowień sprzecznych z naturą spółki akcyjnej lub dobrymi obyczajami). W tym kontek-

${ }^{7}$ I. Komarnicki wskazuje w tym kontekście jedynie na trudność w określeniu wysokości szkody (op. cit.).

${ }^{8}$ A. Herbert, Zagadnienia wstępne, w: System prawa prywatnego, t. 17A: Prawo spótek kapitałowych, red. S. Sołtysiński, Warszawa 2010, s. 348.

${ }^{9}$ Inaczej D. Wajda, która wskazuje, że uporczywe głosowanie przeciw podwyższaniu kapitału zakładowego, mimo że spółka dysponuje środkami na ten cel, może stanowić również czyn niedozwolony w rozumieniu art. 415 k.c. - zob. D. Wajda, Obowiazek lojalności w spótkach handlowych, Warszawa 2009, s. 29.

${ }^{10}$ Zob. bliżej P. Machnikowski, A. Śmieja, A. Olejniczak, Prawo zobowiqzań - część ogólna, w: System prawa prywatnego, t. 6, red. A. Olejniczak, Warszawa 2014, s. 34.

${ }_{11}$ A. Kidyba, M. Dumkiewicz, op. cit., s. 16. 
ście należy również wspomnieć o klauzulach generalnych Kodeksu cywilnego ${ }^{12}$, takich jak dobra wiara (zob. np. art. 344 k.c.), zasady współżycia społecznego (np. art. 5, 56, 65, 354 k.c.), czy względy słuszności (np. art. $417^{2}$ k.c.). W opinii niektórych autorów całokształt wspomnianych norm postępowania kreuje po stronie wspólników obowiązek zachowania lojalności względem siebie ${ }^{13}$.

Pomocne w zrozumieniu i obiektywizacji prawnych, społecznych i ekonomicznych aspektów podziału zysku są koncepcje ochrony mniejszości rozwijane za granica. Na potrzeby analizy warto przybliżyć rozwiązania przyjęte w dwóch - opartych na odmiennych tradycjach - systemach prawa spółek, jakimi sa prawo angielskie i niemieckie.

W porządku angielskim kompetencje organów spółki w sprawie podziału zysku określa umowa spółki. Wypłata dywidendy zazwyczaj wymaga stosownej rekomendacji zarządu i uchwały zgromadzenia ${ }^{14}$. W angielskiej judykaturze nie pojawiły się jak dotąd orzeczenia uwzględniające żądanie podziału zysku ${ }^{15}$. Co do zasady uznaje się, że wspólnikom nie przysługuje prawo do dywidendy, jeśli ta nie została uchwalona. Prawodawca brytyjski ustanowił jednak szeroko ujęte regulacje ukierunkowane na ochronę mniejszości przed nadużyciami. W świetle ustawy o spółkach z 2006 r. (Companies Act) w przypadku, gdy sprawy spółki sa prowadzone w sposób krzywdzący (unfairly prejudicial) dla poszczególnych wspólników (zob. sekcja 994 pkt 1 lit. a), sąd „może wydać postanowienie, jakie uważa za słuszne dla usunięcia nieprawidłowości”. Ta ogólna norma kompetencyjna wyposaża sądy w znaczną autonomię w zakresie oceny i kształtowania relacji w spółce. Sąd może m.in. zobowiązać pozostałych udziałowców lub spółkę do nabycia udziałów od pokrzywdzonej strony (zob. sekcja 996 pkt 2 lit. (e). Takim orzeczeniem zakończyła się przykładowo sprawa Grace v. Biagioli, w której sąd nakazał większościowemu udziałowcowi odkupienie udziałów akcjonariusza bezskutecznie domagającego się podziału zysku $^{16}$. Kwestie związane $\mathrm{z}$ ukształtowaniem dywidendy były też przedmiotem innych postępowań wszczętych na podstawie sekcji 994 pkt $1^{17}$, jednak, co należy zaznaczyć, problem nadmiernej tezauryzacji zysku nie zarysował się w nich jako autonomiczne zagadnienie prawne. Towarzyszyły mu bowiem zawsze inne okoliczności, współtworzące stan pokrzywdzenia mniejszości, np. transfer środków do kontrolujących wspólników.

Z perspektywy polskiego prawa, zważywszy na systemowe podobieństwa, istotne sa rozwiązania przyjęte w porządku niemieckim. Do roku 1986 ustawa z 20 kwietnia 1892 r. o spółce z ograniczoną odpowiedzialnością (GMBHG)

${ }^{12}$ Ustawa z 23 kwietnia 1964 r. - Kodeks cywilny, t.jedn.: Dz. U. 2016, poz. 380 ze zm. (dalej jako: k.c.).

13 Zob. A. Opalski, Obowiazek lojalności w spółkach kapitałowych, „Kwartalnik Prawa Prywatnego" 2008, z. 2, s. 467 i n. oraz D. Wajda, op. cit., i cytowana tam literatura. Por. też wyrok SN z 27 marca 2013 r., I CSK 407/12.

14 P. L. Davies, S. Worthington, Gower \& Davies: Principles of Modern Company Law, London 2012 , s. 298.

15 Ibidem, s. 732 .

${ }_{16}$ Orzeczenie w sprawie Grace v Biagioli [2006] 2 BCLC 70, CA. Por. też sprawa Re a Company (1988) 4 BCLC 506), w której sąd uznał, że wstrzymywanie podziału zysku może uzasadniać rozwiązanie spółki.

17 Por. np. Re Sam Weller \& Sons Ltd [1990] Ch 682, Re a Company (No. 004415 of 1996) [1997] 1 BCLC 479 . 
przewidywała obowiązek wypłaty całości zysku rocznego wspólnikom z zastrzeżeniem, że jednomyślna uchwała zgromadzenia mogła postanowić inaczej. Znowelizowany $§ 29$ GMBHG do pewnego stopnia odwrócił tę zasadę. Stanowi on obecnie, że wspólnikom przysługuje roszczenie o wypłatę zysku „w zakresie, w jakim nie został on wyłączony od podziału uchwałą zgromadzenia wspólników"18. Zmianę tę zinterpretowano początkowo, jako „przejście z jednego ekstremum do drugiego"19, tj. rezygnację z zabezpieczenia przed nieuzasadniona tezauryzacją zysku (Aushungerung), która od tej pory - jak przyjmowano - mogła być bez ograniczeń uchwalana większością głosów. Z upływem czasu doktryna podjęła jednak próby rekonstrukcji nowych reguł ochrony ${ }^{20}$. Stosunkowo szerokie poparcie zdobył m.in. pogląd, że § 29 GMBHG wyposaża wspólników w ogólne (abstrakcyjne) prawo do dywidendy, które unicestwia dopiero ważna uchwała zgromadzenia wspólników o zatrzymaniu zysku w spółce. W przypadku gdy sąd uchyli powyższą uchwałę, wspólnik może wystapić przeciwko spółce z roszczeniem o powzięcie uchwały o wypłacie zysku w całości (Vollausschüttung) ${ }^{21}$. W świetle analogicznie skonstruowanego § 58 ustawy o spółkach akcyjnych (Aktiengesetz - AktG) podkreśla się z reguły abstrakcyjny charakter prawa do dywidendy ${ }^{22}$. W nowszej literaturze pojawił się jednak pogląd, że wspomniane roszczenie o powzięcie uchwały o wypłacie zysku w całości może aktywować się również w „sytuacjach patowych” w spółce akcyjnej ${ }^{23}$.

Powyższy, sumaryczny przegląd zagranicznych doświadczeń nie wystarcza do formułowania stanowczych postulatów co do urealnienia prawa do zysku w polskich spółkach, natomiast sugeruje relatywizację rządów większości w sytuacjach grożących skrajnym pokrzywdzeniem słabszej strony. Taka sugestia przewija się zresztą również w innych porządkach prawnych ${ }^{24}$. W kontekście wzmiankowanych wcześniej uwarunkowań aksjologicznych zachęca to do zgłębienia możliwości funkcjonalnej wykładni zasad ochrony akcjonariuszy na gruncie Kodeksu spółek handlowych.

18 Warto przypomnieć, że w podobnym kierunku ewoluowało polskie prawo (por. art. $191 \S 1$ Kodeksu handlowego).

19 Zob. J. Meyer-Landrut, [Komentarz do § 29], w: J. Meyer-Landrut, F.-G. Miller, R. J. Niehus, Gesetz betreffend die Gesellschaften mit beschränkter Haftung (GmbHG) einschließlich Rechnungslegung zum Einzel - sowie zum Konzernabschluß, Berlin 1987, s. 319.

20 Zob. R. Bork, K. Oepen, Schutz des GmbH-Minderheitsgesellschafters vor der Mehrheit bei der Gewinnverteilung, „Zeitschrift für Unternehmens- und Gesellschaftsrecht” 2002, nr 2, s. 241-291 i cytowana tam literatura.

${ }^{21}$ R. Bork, K. Oepen, op. cit., s. 266 i n.

22 Por. W. Bayer, [Komentarz do § 58], w: Münchener Kommentar zum Aktiengesetz: AktG Band 1: $\$ \S$ 1-75, München 2016, nb. 98-99.

23 A. Cahn, [Komentarz do § 58], w: G. Spindler, E. Stilz (Hrsg.), Kommentar zum Aktiengesetz: AktG Band 1: $\$ \S$ 1-149, wyd. 3, München 2015, nb. 92; umiarkowanie aprobująco również W. Bayer (ibidem, nb. 99).

${ }^{24} \mathrm{~W}$ orzecznictwie francuskim nadmierną tezauryzację uznaje się za nadużycie praw większości (abus de majorité). Taki pogląd wyraził przykładowo Sąd Kasacyjny w wyroku z 7 lutego 2012 r., nakazując podział zysku, zgodnie z żądaniem akcjonariuszy mniejszościowych (Cour de cassation, civile, Chambre civile 3, 11-11.051). W literaturze amerykańskiej szeroko dyskutowanym przykładem ograniczenia rządów większości jest sprawa Dodge v. Ford Motor Co, w której sąd uwzględnił żądanie wypłaty zysku wniesione przez mniejszościowych akcjonariuszy (bracia Dodge), sprzeciwiających się wieloletniej polityce reinwestowania zysków spółki - por. Dodge v. Ford Motor Company, 204 Mich. 459, 170 N.W. 668. (Mich. 1919). 


\section{OCHRONA AKCJONARIUSZY W PRAWIE POLSKIM}

\section{Istota prawa do zysku i granice funkcjonalnej wykładni art. 347 k.s.h.}

Ochrona mniejszości przed naruszeniem prawa do zysku może zasadniczo polegać na umożliwieniu wspólnikom „wyjścia” ze spółki lub stworzeniu mechanizmów ułatwiających wypłatę dywidendy wbrew woli większości. Orzecznictwo Sądu Najwyższego, sankcjonujące możliwość uchylenia uchwały wyłączającej zysk od podziału, sugeruje otwartość na drugi z tych scenariuszy. Ponieważ to właśnie powyższą uchwałę traktuje się jako źródło pokrzywdzenia skarżących, można by sądzić, że zdaniem SN, dopiero wraz z jej powzięciem dopełnia się abuzywny stan faktyczny i prawny. Ergo uchylenie uchwały tezauryzacyjnej powinno przywracać możliwość ochrony, tj. (wobec wykazanego braku roszczeń deliktowych) umożliwiać egzekwowanie dywidendy w drodze przymusu.

Przesłanka urzeczywistnienia „przymusu dywidendowego” powinna być teza, iż akcjonariuszowi przysługuje ogólne uprawnienie do udziału w zysku - rozumiane jako podlegajace ochronie prawo podmiotowe, oddzielne od skonkretyzowanego roszczenia o wypłatę, o którym mowa w art. $347 \S 1$ k.s.h. Istnienie takiego prawa można uznać za warunek konstruowania roszczeń zarówno na podstawie art. 189 k.p.c. ${ }^{25}$, jak i art. 64 k.c. w zw. z 1047 k.p.c. Żaden z powyższych przepisów nie służy bowiem do kreowania przez sąd nowych uprawnień bez stosownej podstawy materialnoprawnej ${ }^{26}$.

Prawo do zysku jest ujmowane w literaturze w sposób zróżnicowany. Z jednej strony podkreśla się, że akcjonariuszowi nie przysługuje jakiekolwiek uprawnienie, oddzielne od roszczenia o wypłatę dywidendy, konkretyzującego się z chwilą powzięcia uchwały walnego zgromadzenia (art. 347 k.s.h.). Prawo do zysku ma charakter abstrakcyjny w tym sensie, że nie stanowi podstawy roszczenia o uzyskanie świadczenia od spółki ${ }^{27}$. Z takiego uprawnienia wypływa co najwyżej obowiązek podjęcia przez zgromadzenie uchwały w sprawie przeznaczenia zysku za ostatni rok obrotowy (art. $231 \S 2$ pkt 2 i art. $395 \S 2$ pkt 2 k.s.h. $)^{28}$, jednak - nie uchwały określonej treści. Z drugiej strony zarówno orzecznictwo, jak i doktryna zdaja się traktować prawo do zysku jako coś więcej niż w istocie twór czysto werbalny, uznajac je przy tym za kategorie odrębna od roszczenia o wypłatę dywidendy ${ }^{29}$. Wskazuje na to powszechność

${ }^{25}$ Ustawa z 17 listopada 1964 r. - Kodeks postępowania cywilnego, t.jedn.: Dz. U. 2014, poz. 101 ze zm. (dalej jako: k.p.c.).

${ }^{26}$ Wyrok w procesie wytoczonym na podstawie art. 189 k.p.c. ma charakter deklaratywny, tj. stwierdza istniejacy już obiektywnie stan praw i stosunków prawnych (por. wyrok Sadu Apelacyjnego w Poznaniu z 26 marca 2008 r., I ACa 200/08). Również przepisy art. 64 k.c. w zw. z art. $1047 \S 1$ k.p.c. nie stanowią samodzielnej podstawy orzeczenia. Wprawdzie sąd orzeka w tym względzie konstytutywnie, ale może opierać się tylko na prawie materialnym, wyznaczającym przesłanki istnienia obowiązku złożenia oświadczenia woli (zob. Z. Radwański, Orzeczenie zastępujace oświadczenia woli, w: System prawa prywatnego, t. 2: Prawo cywilne - część ogólna, red. Z. Radwański, Warszawa 2008, s. 309).

${ }^{27}$ A. Opalski, Prawa akcjonariuszy, w: System prawa prywatnego, t. 17B: Prawo spótek kapitałowych, red. S. Sołtysiński (red.), Warszawa 2010, s. 322.

28 A. Opalski, Kapitat zaktadowy. Zysk. Umorzenie, Warszawa 2002, SIP LexDelta 2016.

${ }^{29}$ Por. np. W. Popiołek, w: Kodeks spótek handlowych. Komentarz, red. J. Strzępka, Warsza- 
wypowiedzi o zabarwieniu wartościujacym, w których wspomniane prawo określa się jako ,jedno z najistotniejszych uprawnień członkowskich”30, „podstawowe prawo majątkowe" ${ }^{31}$ czy ekspektatywę dywidendy ${ }^{32}$.

Mimo odmiennych uwarunkowań normatywnych zachodzi wyraźna zbieżność poglądów na istotę prawa do zysku w literaturze polskiej i niemieckiej. Sugerowałoby to przesłankę do recypowania w polskim systemie koncepcji Vollausschüttung, tj. wyprowadzenia reguły, że - w sytuacji, w której zgromadzenie podejmuje uchwały w sprawie podziału zysku z naruszeniem dobrych obyczajów, a więc niejako blokuje normalny proces wykonywania kompetencji w tym zakresie - akcjonariusze, na podstawie ogólnego uprawnienia do udziału w zysku, mogą ów proces uruchomić na nowo, żądając ustalenia przez sąd, że została powzięta uchwała o podziale zysku w całości. Warto powtórzyć, że takie podejście wyewoluowało w niemieckiej doktrynie w opozycji do pierwotnych interpretacji $§ 29$ GMBHG, które zakładały bezwzględny prymat kapitału i rządów większości.

Należy jednak zauważyć, że art. 347 § 1 k.s.h. stanowi mniej oczywista podstawę niż § 29 GMBHG, czy $§ 58$ AktG, do „upozytywnienia” prawa do dywidendy w drodze wykładni funkcjonalnej. Polski ustawodawca nie sugeruje wcale, aby podział zysku stanowił zasadę, a tezauryzacja wyjątek ${ }^{33}$. Ponieważ na gruncie Kodeksu prawo do zysku należy wywodzić raczej z istoty stosunku korporacyjnego niż konkretnego przepisu, może ono być postrzegane jako słabsza podstawa formułowania roszczeń niż jego (normatywny) odpowiednik w spółce niemieckiej (§58 AktG). Zważywszy na wstrzemięźliwość interpretacyjną polskich sądów i doktryny, można zatem założyć, że konstruowanie roszczenia o powzięcie uchwały o podziale całości zysku w związku z uchyleniem uchwały o jego tezauryzacji wymagałoby silniejszego od naukowych rozważań impulsu prawnego, tj. zmiany art. 347 k.s.h., co najmniej wzorowanej na $\S 29$ GMBHG i $§ 58$ AktG. Wskazanej noweli musiałoby towarzyszyć uporządkowanie jej aspektów procesowych - zwłaszcza przesądzenie o dopuszczalności zastapienia uchwały zgromadzenia orzeczeniem sąu na podstawie art. 64 k.c. w zw. z 1047 k.p.c. Autorzy kwestionujący obecnie taką możliwość argumentuja, że uchwała stanowi szczególna czynność prawna, która odnosi skutek w stosunkach wewnętrznych spółki, a nie oświadczenie woli, składane w imieniu spółki innemu podmiotowi, co w konsekwencji ma uniemożliwiać

wa 2015, s. 836; T. Sójka, Podziat zysku - komentarz do art. 347 KSH, w: S. Sołtysiński, A. Szajkowski, A. Szumański, Kodeks spótek handlowych. Komentarz, t. 3, Warszawa 2013, SIP Legalis 2016. Por. też wyrok WSA z 27 września 2007 r., I SA/Rz 585/07.

${ }^{30}$ A. Opalski, Prawo do udziału w zysku i sposób jego podziału - komentarz do art. $347 \mathrm{KSH}$, w: Kodeks spótek handlowych. Komentarz, t. 3A: Spótka akcyjna, red. A. Opalski, Warszawa 2016, SIP Legalis 2016; wyrok SN z 21 maja 2010 r., II CSK 564/09; podobnie sąd apelacyjny w Krakowie w wyroku z 11 lutego 2015 r., I ACa 1648/14.

${ }^{31}$ J. Frąckowiak et al., Spótka akcyjna, w: System prawa handlowego, t. 2, red. S. Włodyka, Warszawa 2012, SIP Legalis 2016.

${ }^{32}$ Por. T. Sójka, op. cit.; I. Komarnicki, op. cit.; A. Herbert, op. cit., s. 378-379; J. Kuropatwiński, Ekspektatywa powstania wierzytelności w polskim prawie cywilnym, Bydgoszcz 2006, s. 80.

${ }^{33}$ Taką relację przyjmują zwolennicy koncepcji Vollausschüttung na gruncie niemieckiej ustawy o spółce z ograniczoną odpowiedzialnością (zob. R. Bork, K. Oepen, op. cit., s. 266). Poglądy te można odnosić do analogicznie skonstruowanych zasad podziału zysku w spółce akcyjnej. 
zastapienie uchwały orzeczeniem sądu ${ }^{34}$. Powyższy pogląd może być przedmiotem dyskusji. O ile bowiem kwalifikacja uchwały wywołujaccej skutki prawne, jako czynności prawnej, nie budzi wątpliwości ${ }^{35}$, głosowanie na zgromadzeniu stanowi jednocześnie proces formowania się woli organu stanowiącego, która w świetle art. 38 k.c. należy przypisać spółce ${ }^{36}$. Pomimo to nie można wykluczyć, że usunięcie trudności dogmatycznych związanych z zastapieniem uchwały orzeczeniem sądu wymagałoby ostatecznie interwencji ustawodawcy.

\section{Powództwo o ustalenie powzięcia uchwały o podziale zysku}

Brak jednoznacznych perspektyw do zastosowania w polskich realiach koncepcji Vollausschüttung może skłaniać do wykorzystania w inny sposób wyroku uchylającego uchwałę zatrzymująca zysk, a mianowicie jako punktu odniesienia przy kształtowaniu porządku i przebiegu obrad walnego zgromadzenia, zgodnie z art. 401 k.s.h. Wyrok ten, aczkolwiek nie zobowiązuje spółki do świadczenia, wzmacnia pozycję skarżących, ponieważ w pewnym sensie obiektywizuje postulat wypłaty dywidendy i ułatwia zgłoszenie spółce wspólnego projektu nowej uchwały w tej sprawie (art. $401 \S 4$ i 5 k.s.h.). Odrzucenie projektu przez zgromadzenie może stanowić asumpt do kwestionowania głosów blokujących, jako sprzecznych z dobrymi obyczajami, i wniesienia pozwu o ustalenie istnienia (formalnie nieprzegłosowanej) uchwały. Opisany scenariusz będzie zawsze wymagać pogłębionej analizy w okolicznościach konkretnego przypadku, jednakże warto ogólnie zwrócić uwagę na następujące kwestie.

Zdaniem niektórych autorów uznanie, iż w określonych okolicznościach wspólnicy mają obowiązek opowiedzenia się za uchwałą o podziale zysku, „stanowiłoby wypaczenie istoty przysługującego im prawa głosu” ${ }^{37}$. Pogląd ten wydaje się zbyt daleko idący, a co najmniej zbyt uogólniony. W analizowanym kontekście pojęcie obowiązku można bowiem rozpatrywać w dwóch płaszczy-

${ }^{34}$ A. Opalski, Kapitat...

${ }^{35} \mathrm{~W}$ projekcie nowego kodeksu cywilnego - Księgi pierwszej kwalifikację tę określono jako „niekwestionowaną" (por. art. 81 oraz uzasadnienie projektu; dostępne na www.bip.ms.gov.pl). Zob. też P. Antoszek, Cywilnoprawny charakter uchwat wspólników spótek kapitałowych, Warszawa 2009 i cytowana tam literatura.

${ }^{36}$ W. Popiołek określa uchwałę, jako „zbiorową czynność prawną” lub „zbiorowe oświadczenie woli” (zob. Charakter prawny uchwat wspólników i organów spótek handlowych, „Przegląd Prawa Handlowego" 2014, nr 9, s. 13). Na dwoisty charakter uchwały zwraca też uwagę M. Gutowski, wyróżniając oświadczenia woli poszczególnych osób w akcie głosowania, oświadczenie woli osoby prawnej w postaci uchwały oraz ewentualną czynność prawną którą konstytuować może uchwała (M. Gutowski, Nieważność czynności prawnej, Warszawa 2008, s. 27). Na możliwość zastapienia orzeczeniem sądu tzw. uchwał przymusowych wskazywali też M. Fras (Wzajemna relacja pomiędzy art. 64 KC a art. 624 KSH - próba oceny, „Palestra” 2008, nr 304, s. 9 i n.) oraz M. Jasiakiewicz (Wybrane problemy stosowania art. 64 k.c. do uchwat przymusowych niepodjętych przez zgromadzenie wspólników spótki kapitałowej, „Przegląd Prawa Handlowego” 2014, nr 10, s. 45 i n.). Elastyczne podejście do analogicznej kwestii zaproponowano w doktrynie niemieckiej. R. Bork, K. Oepen wskazuja, przykładowo, że wprawdzie uchwała stanowi czynność prawna, jednak w sensie wykonawczym - może zostać ukształtowana przez sąd również jako oświadczenie woli, co pozwala zastapić ją orzeczeniem wydanym na podstawie $\S 894$ niemieckiego kodeksu procedury cywilnej, stanowiącego odpowiednik art. 1047 k.p.c. (zob. R. Bork, K. Oepen, op. cit., s. 250).

${ }^{37}$ Zob. A. Kidyba, M. Dumkiewicz, op. cit., s. 11-16. 
znach. Obowiązek określonego głosowania nie istnieje jako korelat odpowiedzialności odszkodowawczej, gdyz - jak wyjaśniono - nie ma podstaw do przyjmowania takiej odpowiedzialności w sprawach podziału zysku. Natomiast, co należy podkreślić, ustawodawca ogranicza swobodę głosu w wymiarze ogólnym, dopuszczając zaskarżanie uchwał. Akcjonariusze jako kolektyw maja więc obowiązek głosować tak, aby rozstrzygnięcie zgromadzenia nie naruszało dobrych obyczajów i nie krzywdziło mniejszości. Sankcją w tym przypadku jest ewentualne uchylenie uchwały (art. 422 k.s.h.).

Można rozważać dwie koncepcje podważenia głosów naruszających dobre obyczaje. Przyjmujac, że w opisanej sytuacji dochodzi do powzięcia swoistej uchwały odmownej (względnie uchwały negatywnej), właściwe byłoby zaskarżenie tej ostatniej na podstawie art. 422 k.s.h. Natomiast uznając, że głosy blokujące uniemożliwiają ukonstytuowanie się jakiejkolwiek czynności prawnej, należałoby rozważać powództwo o ustalenie ich nieważności (art. 189 k.p.c.) na podstawie analogii z art. 58 § 2 k.c. w zw. z 354 k.c. i art. 2 k.s.h. ${ }^{38}$ Powyższe otwierałoby droge do wspomnianej „reaktywacji” odrzuconej uchwały w drodze powództwa wytoczonego spółce na podstawie art. 189 k.p.c.

Analizowane działania wychodzą poza typowy schemat rozwiazywania konfliktów korporacyjnych (wyeliminowanie spornej uchwały z obrotu), a w konsekwencji rodzą pytania i dylematy. Przede wszystkim trzeba wskazać, że dopuszczalność powództwa o ustalenie istnienia uchwały nie jest w polskim prawie przesądzona $^{39}$. Niezależnie od wzmiankowanych kontrowersji na gruncie prawa i procedury cywilnej (zob. wyżej pkt 1 in fine), ogólnych założeń takiej koncepcji nie konfrontowano z problematyka podziału zysku. Usankcjonowanie uchwały na drodze procesowej nasuwa tymczasem pewne wątpliwości, związane z przypisaniem funkcji quasi-zarządczych sądowi, który - jako instancja zewnętrzna nie ponosi odpowiedzialności organizacyjnej przed spółką za efekty swoich dzia$\mathfrak{ł a n ́}^{40}$. Powyższy problem w mniejszym stopniu dotyczy uchwał będących swoista „antytezą" uchylonych rozstrzygnięć (np. uchwała udzielająca absolutorium po uchyleniu uchwały odmownej). Podważenie uchwały o tezauryzacji zysku otwiera jednak całe spektrum możliwości jego podziału. Wybór jednego z nich stanowi w dużej mierze kwestię pozaprawna, w której istotną rolę odgrywa zarówno rachunek ekonomiczny spółki, jak i preferencje poszczególnych interesariuszy.

\footnotetext{
38 Obydwa podejścia charakteryzuje P. M. Wiórek, Powództwo o ustalenie podjęcia uchwaty, „Przegląd Prawa Handlowego” 2014, nr 12, s. 11-16. Na możliwość uznania głosów za nieważne w przypadku naruszenia wskazał wcześniej A. Opalski, rozważając jednak wyłącznie „nakaz głosowania w określony sposób, gdy jest to niezbędne dla realizacji wspólnego celu, rozstrzygającego o istnieniu spółki” (zob. A. Opalski, Obowiazek..., s. 477). W późniejszych wypowiedziach autor sygnalizował jednak sporność powyższego zagadnienia, wykluczając jednocześnie możliwość stwierdzenia wadliwości głosowania w postępowaniu sądowym (A. Opalski, Obowiqzki..., s. 381). Krytycznie o zaskarżalności indywidualnych głosów P. Antoszek (op. cit., s. 143). Por. też. M. Fras, op. cit., s. 9 i n. oraz M. Jasiakiewicz, op. cit., s. 45 i n.

${ }^{39}$ Analizuje ją aprobująco P. M. Wiórek, op. cit., s. 54 i n. Umiarkowanie przychylny (wskazując na wątpliwości konstrukcyjne) wydaje się S. Sołtysiński, Walne zgromadzenie, w: System prawa prywatnego, t. 17B, s. 606. Na gruncie Kodeksu handlowego sceptycznie wypowiedział się o takiej koncepcji A. W. Wiśniewski, „Uchwała negatywna” w spółce kapitałowej, „Radca Prawny” 1992, nr 3, s. 28. Por. też uwagi w rozdziale 3.1 in fine oraz literaturę cytowaną w przypisie 36.

${ }^{40}$ A. W. Wiśniewski, op. cit., s. 28.
} 
Zróżnicowanie celów akcjonariuszy mniejszościowych może skutkować konkurencja projektów uchwał o podziale zysku, która utrudni wniesienie analizowanego powództwa. Poddanie danej propozycji pod głosowanie, a następnie zarejestrowanie jej treści i ewentualnych głosów przeciwnych (art. $421 \S 2$ k.s.h.) w praktyce często zależy od decyzji protokolanta i przewodniczacego zgromadzenia. Ten ostatni może ograniczać ze względów porządkowych uprawnienie do zgłaszania projektów uchwał ${ }^{41}$, jak również określając kolejność głosowania, rozstrzygać, czy powzięcie uchwały w jednej z proponowanych wersji czyni bezprzedmiotowym głosowanie nad inną wersja ${ }^{42}$.

Powyższe uwagi nie przekreślają możliwości wykorzystania powództwa o ustalenie istnienia uchwały $\mathrm{w}$ sporach o podział zysku. Istotę ingerencji sądu w wewnętrzne sprawy spółki należałoby dostrzegać nie tyle we wskazaniu przez sąd „sprawiedliwej” kwoty dywidendy, ile w dokonaniu oceny, czy głosy oddane za konkretna propozycją akcjonariuszy są zgodne z dobrymi obyczajami (która to ocena nie odbiega zasadniczo od weryfikacji w postępowaniu sądowym uchwał, związanych z innymi sprawami o charakterze gospodarczym ${ }^{43}$ ). Wobec sygnalizowanych trudności prawnych i organizacyjnych powyższy scenariusz nie gwarantuje rozwiązania problemu nadużyć we wszystkich rodzajach spółek, niemniej w pewnych ramach faktycznych (np. w spółkach o nieskomplikowanej strukturze kapitałowej) otwiera realna perspektywę konfrontowania postulatów mniejszości z działaniami akcjonariuszy większościowych. Opisana koncepcja dostarczałaby celowościowych argumentów za elastycznym podejściem do kwestii zaskarżania indywidualnych głosów oraz zastapienia uchwały zgromadzenia orzeczeniem sądu.

\section{Uwagi de lege ferenda}

Przeprowadzona analiza sugeruje jednocześnie potrzebę wzmocnienia praw mniejszości. Wobec funkcjonalnych ograniczeń „przymusu dywidendowego” de lege ferenda należałoby uwzględnić alternatywne możliwości ochrony - przykładowo, ułatwienie wspólnikom wyjścia z „toksycznej” spółki przez wykup akcji. Kształt rozwiązań prawnych w powyższym zakresie jest zagadnieniem otwartym. Warto jednak zauważyć, że nie muszą one być poświęcone wyłącznie problematyce dywidendowej ani też nie muszą powielać, obecnie funkcjonującego na gruncie Kodeksu, normatywnego wzorca wykupu akcji (jako opcji automatycznie aktywującej się w określonej sytuacji istniejącego lub potencjalnego konfliktu, względnie zachwiania równowagi w spółce $\left.{ }^{44}\right)$. Przeciwko

${ }^{41}$ Zob. W. Popiołek, op. cit, s. 990.

${ }^{42}$ Por. M. Rodzynkiewicz, Kodeks spótek handlowych. Komentarz, Warszawa 2012, s. 807.

${ }^{43}$ Por. np. orzeczenie z 15 maja 2007 r., I ACa 339/07, w którym Sąd Apelacyjny w Warszawie stwierdził, że „Sąd zasadniczo nie zajmuje się kontrolą polityki ekonomicznej spółki. Gdy jednak bada zasadność zaskarżonych uchwał, np. o niewypłacaniu dywidendy, może weryfikować trafność konkretnych inwestycji”.

${ }^{44}$ Por. np. art. $416 \S 4,516 \S 3$ i art. $541 \S 5$ k.s.h. Zob. też art. 17 i 48 ustawy z 4 marca 2005 r. o europejskim zgrupowaniu interesów gospodarczych i spółce europejskiej, t.jedn.: Dz. U. 2015, poz. 2142. 
usztywnieniu (zautomatyzowaniu) ewentualnej regulacji prawnej przemawia niejednorodność konfliktów korporacyjnych. W analizowanym kontekście ujawnia się raczej potrzeba szerszej reformy systemu ochrony mniejszości i zorientowania go na dyskrecjonalne instrumenty zwalczania nadużyć. Dobrym przykładem takiego podejścia jest prawo angielskie, w którym - jak wspomniano - nie tylko konkretyzacje pojęcia pokrzywdzenia (unfair prejudice), ale i dobór środków ochrony pozostawia się sądom. Oprócz zobowiązania do wykupu udziałów wspólnika, sądy angielskie moga, przykładowo, „odpowiednio uregulować sprawy spółki w przyszłości” ${ }^{45}$ lub „zobowiąać spółkę do podjęcia określonego działania, zgodnego z żądaniem powoda” ${ }^{46}$ - przy czym katalog możliwych rozstrzygnięć, wymienionych w sekcji 996(2) ustawy o spółkach jest otwarty. Powyższe regulacje, funkcjonujace we współczesnej formie od 1980 r., zerwały z tradycją nieingerowania w wewnętrzne stosunki korporacyjne i ukształtowały w zakresie ochrony mniejszości system faktycznego współdzielenia kompetencji prawotwórczej przez ustawodawcę i sądy ${ }^{47}$.

Doświadczenia zagraniczne potwierdzają jednocześnie, że uwolnienie wspólnika z abuzywnej relacji korporacyjnej niesie ze sobą szereg złożonych i potencjalnie spornych zagadnień, których rozwiązanie nie jest możliwe bez uregulowania w statucie przesłanek i szczegółów takiej operacji, względnie bez udziału (asysty) sądu, gwarantującego pewność prawa i poszanowanie dla stabilności stosunku spółki. W tym kontekście kontrowersyjne są koncepcje jednostronnego wypowiedzenia udziału korporacyjnego, które kładą nacisk na kontraktowe elementy stosunku spółki kapitałowej, odsuwając jednocześnie na dalszy plan jego aspekty organizacyjne i specyficzne uwarunkowania prawa spółek (przykładowo w zakresie wyceny akcji/udziałów wycofującego się wspólnika, ustawowych ograniczeń w nabywaniu przez spółkę własnych akcji/ udziałów, czy formy czynności prawnej przeniesienia udziałów) ${ }^{48}$.

\section{PODSUMOWANIE}

Formułowanie postulatów interpretacyjnych ukierunkowanych na egzekwowanie podziału zysku w imię zrównoważonej polityki dywidendowej można uznać za obarczone wadą petitio principi, ponieważ wymóg prowadzenia takiej polityki nie wynika z Kodeksu spółek handlowych. Jednocześsnie jednak trudno zaakceptować w tym względzie regułę rządów większości w ujęciu absolutnym, tj. dopuszczająca podważenie ekonomicznego sensu inwestycji kapitałowej mniejszościowych udziałowców. Istota stosunku spółki (art. 3 k.s.h.), nakaz jednakowego traktowania wspólników (art. 20 k.s.h.),

${ }^{45}$ Sekcja 996 (2) (a) Companies Act.

${ }^{46}$ Sekcja 996 (2) (b) (ii) Companies Act.

${ }_{47}$ P.L. Davies, S. Worthington, op. cit., s. 721 i n.

${ }^{48}$ Za możliwością wypowiedzenia udziału w spółce z ograniczoną odpowiedzialnością, pomimo braku regulacji ustawowej, opowiedział się przykładowo A. Kappes, Uwolnienie „więźnia korporacyjnego” spótki z o.o. przez wypowiedzenie udziału w spółce, „Przegląd Prawa Handlowego” 2015, nr 10 , s. 38 . 
możliwość zaskarżania uchwał zgromadzenia (art. 249 § 1 i 422 § 1 k.s.h.), klauzule generalne Kodeksu cywilnego, a wreszcie ogólnosystemowa zasada równorzędności stron stosunku obligacyjnego, uzasadniają funkcjonalna analizę reguł podziału zysku, w celu zapewnienia słabszej stronie minimum ochrony prawnej.

Powyższe podejście koresponduje z rozwijaną w polskiej i zagranicznej doktrynie koncepcją obowiązku lojalności między wspólnikami (Treupflicht). Koncepcja ta nie dostarcza jednak argumentów za uwzględnieniem jakichś konkretnych, a zarazem uniwersalnych postulatów w zakresie dysponowania zyskiem. Wynika to m.in. z tego, że charakter, intensywność, a nawet samo istnienie „obowiązku lojalności” zależą od indywidualnych cech spółki (jej rodzaju i wielkości, struktury akcjonariatu itp.). Ponadto posługiwanie się pojęciem obowiązku uzasadniałoby wskazanie sankcji za naruszenie powiązanego z nim prawa (ubi ius, ibi remedium), czego w odniesieniu do blokady dywidendy w literaturze przedmiotu nie uczyniono.

Artykuł 347 k.s.h. nie stanowi jednoznacznej przesłanki do „upozytywnienia" prawa do zysku, na wzór niemieckiej konstrukcji Vollausschüttung. Można sądzić, że implementacja takiego rozwiązania wymagałaby zmiany Kodeksu nawiąującej do $§ 58$ niemieckiej ustawy o spółkach akcyjnych. De lege lata silniejszym punktem oparcia dla akcjonariuszy wydają się przepisy art. 401 k.s.h, umożliwiajace zgłoszenie spółce projektu uchwały o podziale zysku. W okolicznościach konkretnego przypadku może to kreować przesłankę do wniesienia powództwa o ustalenie istnienia uchwały, zgodnej z projektem. Wobec wzmiankowanych ograniczeń takiego scenariusza, sens i „zastosowalność” orzeczeń uchylających uchwały w sprawie tezauryzacji zysku nie sa jednak oczywiste. Taki stan rzeczy może powodować dezorientację uczestników obrotu ${ }^{49}$, a jednocześnie subiektywizm i arbitralność osądów orzecznictwa, w niedostatecznym stopniu konfrontowanych $\mathrm{z}$ praktyka ${ }^{50}$.

Powyższe wskazuje na potrzebę usprawnienia systemu ochrony mniejszości. Punktem odniesienia postulatów de lege ferenda mogą być przepisy angielskiej ustawy o spółkach, umożliwiające sądom wydawanie „postanowień, jakie są konieczne do usunięcia nieprawidłowości”. Zważywszy, że - jak trafnie pisał Zygmunt Ziembiński - prawodawca może sporządzić tylko pseudobilans strat i zysków związanych z wyborem określonego rozwiązania prawnego ${ }^{51}$, silną strona systemu angielskiego jest aktywna rola sądów w kształtowaniu zasad ochrony mniejszości. Jak jednocześnie potwierdzają doświadczenia sądów angielskich (zob. pkt II) abuzywna tezauryzacja zysku z reguły nie stanowi celu samego w sobie - towarzyszą jej rozmaite próby transferowania

${ }^{49}$ Zob. M. Miedziński, Nie można krzywdzić wspólników, „Rzeczpospolita” z 23 października 2015 r.

50 Wśród poglądów otwartych na dyskusję można, przykładowo, wymienić zapatrywanie Sądu Najwyższego, wyrażone w wyroku z 27 marca 2013 r. (I CSK 407/12), iż tezauryzacja zysku jest nieuzasadniona również z uwagi na „przeinwestowanie” spółki (tj. - jak należy rozumieć również, gdy nie towarzyszy temu transfer korzyści do większościowych akcjonariuszy).

51 Z. Ziembiński, Problemy podstawowe prawoznawstwa, Warszawa 1980, s. 399-400. 
środków do większościowego udziałowca (tzw. ukryte wypłaty). Kluczem do rozwiązania tak rysującego się problemu wydają się nie tyle przepisy zwiększające wpływ mniejszości na podział zysku (np. wzorowane na koncepcji Vollausschüttung), ile elastyczne instrumenty kontroli sądowej, które umożliwiają pragmatyczne i zgodne z poczuciem słuszności reagowanie na konkretne okoliczności faktyczne.

mgr Michat Miedziński

radca prawny, Warszawa

mmiedzinski@kpmg.pl

\author{
PROTECTING MINORITY SHAREHOLDERS AGAINST \\ THE ABUSIVE RESTRICTIONS ON PROFIT DISTRIBUTION
}

Sum mary

Distribution of yearly profits in companies raises complex issues pertaining to the statutory framework of shareholder relationship. Under Article 191 and 347 of the Code of Commercial Partnerships and Companies the above matter is decided by the resolution passed at the annual general meeting and (as such) is left to the discretion of the controlling members. Notably, the general meeting can retain profits in the company or declare low dividends. However, in light of the Supreme Court's decisions, the above resolution, reflecting only the interests of the majority, can be viewed as oppressive for the minority and consequently set aside in court. The consequences of the court ruling are, nonetheless, unclear, as it does not imply an obligation on the company to pay higher dividends. Some authors go as far as to argue that the ruling itself is of no value to the claimants and that the majority rule in Polish company law is unconditional and absolute. The article explores the above issue in the context of a public limited company and attempts to answer the question of whether the minority shareholders can protect their rights in the event of excessive (abusive) restrictions on profit distribution. 
